\title{
Pengujian Black Box pada Perangkat Lunak Sistem Penilaian Mahasiswa Menggunakan Teknik Boundary Value Analysis
}

\author{
Debiyanti Debiyanti $^{1}$, Sutrisna Sutrisna ${ }^{2}$, Budrio Budrio ${ }^{3}$, Alvin Kurnia Kamal ${ }^{4}$, Yulianti Yulianti ${ }^{5}$ \\ Teknik Informatika, Universitas Pamulang, Jl. Raya Puspitek No.46, Buaran, Serpong, Tangerang \\ Selatan, Banten, Indonesia, 15310 \\ e-mail: 1dhebbyyantii@gmail.com, ${ }^{2}$ trisnafalky@gmail.com, ${ }^{3}$ budriorio35@gmail.com, \\ ${ }^{4}$ alvinkurniakamal@gmail.com, ${ }^{5}$ yulianti@unpam.ac.id
}

Submitted Date: June $07^{\text {th }}, 2020$

Revised Date: June $30^{\text {th }}, 2020$
Reviewed Date: June $17^{\text {th }}, 2020$

Accepted Date: June $30^{\text {th }}, 2020$

\begin{abstract}
With this student assessment application, if there is an error in the program, there will be losses for students and universities. The loss that is in the natural student, if this application has an error (trouble) then the student assessment process will be delayed and difficult in the calculation of the value of students and students will be late in obtaining the value. The losses are in the natural universities where students want a quick assessment process but the university cannot calculate quickly and precisely. Method used in this application use black box method with boundary value analysis technique. The boundary value analysis technique measures application's assessment if there is an error when entering data that will be tested in the field to determine the value has been valid or no more errors will be stored in the database. The test is done on the Student assessment form by measuring the upper limit value and lower limit value through several predefined stages for each of the columns in the form. Test results can be input to improve the application. The results of this test can provide reference to the quality testing of the student assessment application by analyzing the functionality of the programs that have been made in accordance with the results expected
\end{abstract}

Keywords: Information System; Assessment; Testing Black Box; Boundary Value Analysis

\section{Abstrak}

Dengan aplikasi penilaian mahasiswa ini, jika terdapat kesalahan pada program maka akan timbulnya kerugian bagi mahasiswa dan universitas. Kerugian yang dialami mahasiswa, bila aplikasi ini mengalami kesalahan(trouble) maka proses penilaian mahasiswa akan mengalami keterlambatan dan sulit dalam perhitungan nilai mahasiswa dan mahasiswa akan terlambat dalam memperoleh nilai. Kerugian yang dialami universitas bila mana mahasiswa menginginkan proses penilaian yang cepat tetapi universitas tidak bisa menghitung dengan cepat dan tepat. Metode yang digunakan dalam aplikasi ini menggunakan metode black box dengan teknik boundary value analysis. Teknik boundary value analysis mengukur kulitas aplikasi bila masih terdapat kesalahan saat memasukan data yang akan diuji pada kolom untuk menentukan nilai tersebut telah valid atau tidak adanya lagi kesalahan yang akan tersimpan di database. Pengujian dilakukan pada form Penilaian Mahasiswa dengan mengukur nilai batas atas dan nilai batas bawah melalui beberapa tahapan yang telah ditentukan untuk masing masing kolom yang ada di dalam form tersebut. Hasil pengujian dapat dijadikan masukan untuk memperbaiki aplikasi. Hasil dari pengujian ini dapat memberikan referensi atas pengujian kualitas aplikasi penilaian mahasiswa dengan menganalisa fungsionalitas dari program yang sudah dibuat sesuai dengan hasil yang di harapkan.

\section{Kata Kunci: Sistem Informasi; Penilaian; Pengujian Black Box; Boundary Value Analysis}

\section{Pendahuluan}

Pengujian perangkat lunak merupakan sebuah proses pengujian program yang dimaksudkan untuk mencari

pada software. Pengujian juga

kesalahan 
kualitas yang baik. Kualitas software yang baik adalah software memenuhi kriteria yang diinginkan dan memberikan produktivitas yang tinggi (MZ, 2016). Pengujian perangkat lunak penting adanya untuk melakukan uji kualitas perangkat lunak agar menekan peluang terjadinya kesalahan. Pengujian sangat diperlukan dalam sistem informasi untuk memastikan aplikasi yang dikembangan telah memenuhi persyaratan teknis dan bisnis yang diharapkan sebelum diserahkan kepada pengguna (customer) (Febrian, Ramadhan, Faisal, \& Saifudin, 2020). Hal ini menunjukkan bahwa hasil pengembangan perangkat lunak sangat bergantung pada jaminan kualitas software (Liana, 2015).

Pengujian perangkat lunak memiliki peranan penting dalam suatu sistem informasi, dengan pengujian ini dapat diketahui cacat atau error yang akan muncul pada perangkat lunak. Software yang cacat atau mengandung kesalahan dapat memberikan hasil yang tidak sesuai harapan dan dapat menyebabkan kerugian yang besar (Saifudin \& Yulianti, 2020). Dengan pengujian perangkat lunak diharapkan dapat meminimalisir kesalahan dan cacat pada sebuah software dan sebagai pengukuran kualitas dari software tersebut (Kurniawan, 2017). Sehingga sangat perlu melakukan pengujian untuk mengurangi terjadinya kesalahan yang merugikan tersebut (Ningrum, Suherman, Aryanti, Prasetya, \& Saifudin, 2019).

Perangkat Lunak yang akan diuji adalah sebuah aplikasi penilaian mahasiswa. Aplikasi Sistem Informasi Penilaian Mahasiswa merupakan sistem untuk memasukan data penilaian mahasiswa yang masuk ke database. Aplikasi ini dapat menghitung nilai keseluruhan dari nilai kehadiran, nilai tugas, nilai uts, dan nilai uas.

Bagi mahasiswa, jika aplikasi ini terjadi trouble maka penilaian yang diterima mahasiswa akan mengalami keterlambatan dikarenakan sulit dalam proses penghitungan nilai mahasiswa dan mahasiswa akan terlambat menerima penilaian. Kerugian bagi universitas, jika terjadi program trouble pada aplikasi ini, universitas akan mengalami kerugian jika mahasiswa menginginkan penurunan penilaian dengan cepat tapi universitas tidak bisa menghitung dengan cepat dan tepat.

Masalah yang ada pada sistem ini yaitu terdapat kesalahan pada saat memasukkan nilai. Sistem ini tetap dapat menghitung dan menampilkan nilai yang lebih dari 100 atau kurang dari 0. Aplikasi ini tidak dapat mengubah data yang sudah dimasukkan ke dalam database.

Metode usulan yang digunakan untuk menguji kualitas aplikasi ini adalah metode black box dengan teknik boundary value analysis. Teknik boundary value analysis digunakan untuk menentukan nilai batas bawah dan batas atas dari data yang ingin diuji (Jaya, 2018).

Berdasarkan metode pengujian yang diusulkan, maka dapat dibuat tahapan-tahapan pengujian perangkat lunak ini. Tahapantahapan atau rencana dalam melakukan pengujian ini yaitu dengan menentukan nilai batas atas dan nilai batas bawah melalui beberapa tahapan yang telah ditentukan untuk masing-masing kolom dan membangun kasus untuk digunakan dalam pengujian (Wahyu, 2018).

\section{Metodologi}

Pengujian merupakan bagian utama dari pengembangan software, karena kegagalan pengujian dapat menimbulkan kerugian yang besar (Aziz, Setiawan, Khanh, Nurdiyansyah, \& Yulianti, 2020). Tujuan dari pengujian adalah untuk memastikan bahwa sistem yang dihasilkan sesuai dengan kebutuhan dan layak untuk digunakan (Arwaz, Putra, Putra, Kusumawijaya, \& Saifudin, 2019). Sehingga dalam melakukan pengujian harus memilih teknik yang tepat, yaitu teknik yang dapat menemukan kesalahan yang belum terdeteksi sehingga dapat meningkatkan kualitas software (Hendri, Manurung, Ferian, Hanaatmoko, \& Yulianti, 2020).

Boundary value analysis adalah teknik pengujian perangkat lunak di mana tes dirancang untuk mencakup perwakilan dari nilai batas dalam kisaran. Idenya berasal dari batas. Mengingat bahwa kita memiliki satu set vektor uji untuk menguji sistem, topologi dapat didefinisikan di set itu. Teknik boundary value analysis digunakan untuk menentukan nilai batas bawah dan batas atas dari data yang ingin diuji dengan dengan menguji nilai batas atas dan nilai batas bawah melalui beberapa tahapan yang telah ditentukan untuk masing-masing field dan membangun kasus untuk digunakan dalam pengujian (Astuti, 2018). 


\section{Boundary Value Analysis}

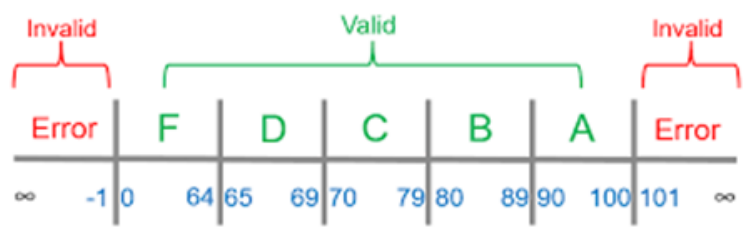

\section{Gambar 1 Desain Teknik Boundary Value Analysis}

Analisis nilai batas atau disebut juga Boundary value analysis, dirancang untuk mencakup perwakilan dari nilai batas dalam kisaran nilai 0 sampai 100 , tidak dapat menerima nilai kurang dari 0 , dan tidak dapat menerima nilai lebih dari 100. Beberapa prinsip yang mendasari pada Boundary Value Analysis yaitu (Nurudin, Jayanti, Saputro, Saputra, \& Yulianti 2019):

1. Terdapat beberapa kesalahan yang terjadi pada masukan.

2. Boundary Value Analysis mengijinkan untuk menentukan kasus uji yang menguji batasan nilai masukan.

3. Boundary Value Analysis merupakan komplemen dari equivalence partitioning. Lebih berfokus pada menentukan elemen- elemen di dalam kelas ekuivalen pada bagian sisi batas dari kelas.

\section{Hasil dan Pembahasan}

Hasil dari pengujian tersebut kemudian di catat ke dalam kolom hasil uji. Berdasarkan hasil dari pengujian kemudian dapat menentukan kesimpulan dengan menyesuaikan antara hasil yang diuji dan hasil yang diharapkan. Jika hasil yang diuji sesuai dengan hasil yang diharapkan maka kesimpulannya adalah berhasil. Jika hasil diuji tidak sesuai dengan hasil yang diharapkan maka kesimpulannya adalah gagal.

Dari form pada Gambar 2 terdapat beberapa masukan. Masukan Nama menerima masukan berupa huruf, berdasarkan teknik boundary value analysis, contoh nilai masukan yang valid antara a-Z \& A-Z sedangkan yang tidak valid 0-9. Masukan NIM menerima masukan berupa angka, berdasarkan teknik boundary value analysis, contoh nilai masukan yang valid antara 0-9 sedangkan yang tidak valid a-z \& A-Z. Masukan Nilai Kehadiran menerima masukan berupa angka, berdasarkan teknik boundary value analysis, contoh nilai masukan yang valid antara $0-9$ sedangkan yang tidak valid a-Z \& A-Z.

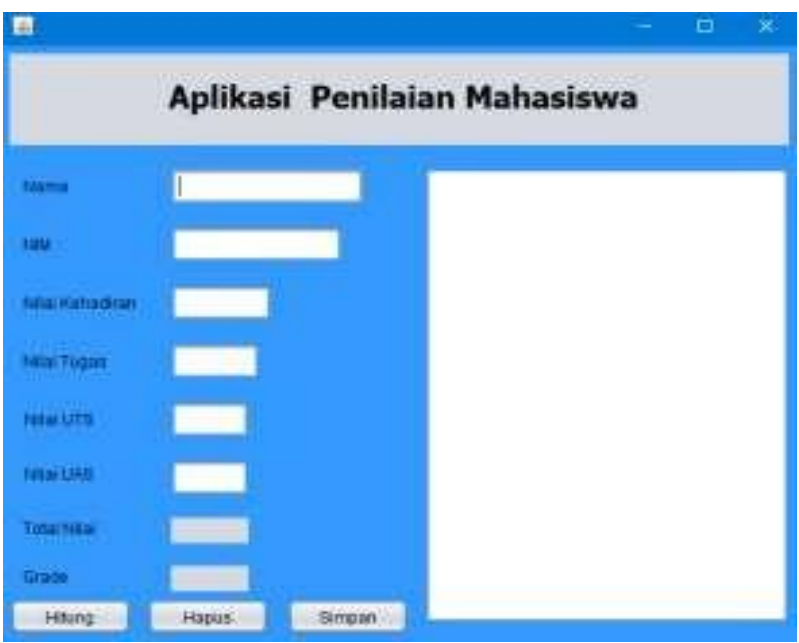

Gambar 2. Form Penilaian Mahasiswa

Masukan Nilai Tugas menerima masukan berupa angka, berdasarkan teknik boundary value analysis, contoh nilai masukan yang valid antara 0-9 sedangkan yang tidak valid a-z \& A-Z. Masukan Nilai UTS menerima masukan berupa angka, berdasarkan teknik boundary value analysis, contoh nilai masukan yang valid antara 0-9 sedangkan yang tidak valid a-z \& A-Z.

Masukan Nilai UAS menerima masukan berupa angka, berdasarkan teknik boundary value analysis, contoh nilai masukan yang valid antara 0-9 sedangkan yang tidak valid a-z \& A-Z. Karena pada kolom Total Nilai dan Grade bukan merupakan kolom masukkan, jadi tidak ada pengujian masukkan nilai.

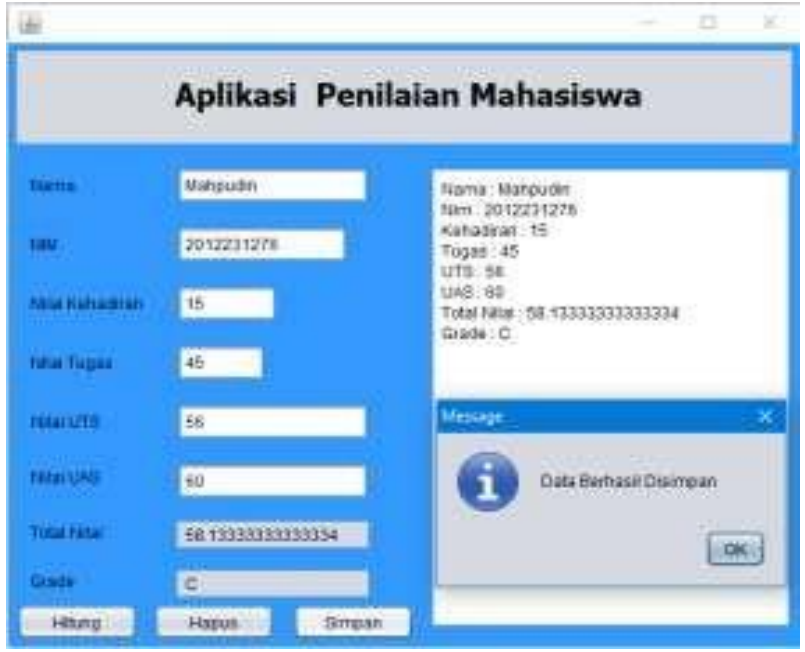

Gambar 3.Hasil Tambah Data Mahasiswa 
Dari form pada Gambar 4 merupakan hasil dari penambahan data nilai yang telah dimasukkan oleh user untuk data penilaian mahasiswa yang terdiri dari Nama, NIM, Nilai Kehadiran, Nilai Tugas, Nilai UTS, Nilai UAS, dan ada aksi untuk menghitung Total Nilai dan Grade serta aksi untuk menyimpan dan menghapus data penilaian mahasiswa.

Tabel 1. Test case

\begin{tabular}{|c|c|c|c|c|}
\hline Test ID & Deskripsi & Hasil yang diharapkan & Hasil Pengujian & Status \\
\hline CS1 & $\begin{array}{l}\text { Masukan kolom Nama, } \\
\text { NIM, Nilai Kehadiran, } \\
\text { Nilai Tugas, Nilai } \\
\text { UTS, } \\
\text { Nilai UAS lalu tekan } \\
\text { tombol Hitung. }\end{array}$ & $\begin{array}{l}\text { Sistem akan menghitung dan } \\
\text { menampilkan data yang sudah } \\
\text { diisi pada form penilaian } \\
\text { mahasiswa. }\end{array}$ & $\begin{array}{l}\text { Sistem menghitung } \\
\text { dan menampilkan } \\
\text { data. }\end{array}$ & Berhasil \\
\hline $\mathrm{CS} 2$ & $\begin{array}{l}\text { Mengosongkan salah } \\
\text { satu kolom pada form } \\
\text { lalu tekan tombol Hitung. }\end{array}$ & $\begin{array}{l}\text { Sistem tidak akan menghitung } \\
\text { dan menampilkan data yang } \\
\text { sudah diisi pada form penilaian } \\
\text { mahasiswa dan akan } \\
\text { menampilkan pesan "Ada Data } \\
\text { Yang Belum Diisi". }\end{array}$ & $\begin{array}{l}\text { Sistem tidak } \\
\text { menghitung dan } \\
\text { menampilkann data } \\
\text { dan menampilkan } \\
\text { pesan "Ada Data } \\
\text { Yang Belum Diisi". }\end{array}$ & Berhasil \\
\hline $\mathrm{CS} 3$ & $\begin{array}{l}\text { Tidak memasukkan } \\
\text { kolom Nama, NIM, } \\
\text { Nilai Kehadiran,Nilai } \\
\text { Tugas, } \\
\text { Nilai UTS, Nilai UAS } \\
\text { lalu tekan tombol Hitung. }\end{array}$ & $\begin{array}{l}\text { Sistem tidak akan menghitung } \\
\text { dan menampilkan data yang } \\
\text { sudah diisi pada form penilaian } \\
\text { mahasiswa. }\end{array}$ & $\begin{array}{l}\text { Sistem tidak } \\
\text { menghitung dan } \\
\text { menampilkan data. }\end{array}$ & Berhasil \\
\hline CS4 & $\begin{array}{l}\text { Masukan kolom Nama, } \\
\text { NIM, Nilai } \\
\text { Kehadiran,Nilai Tugas, } \\
\text { Nilai UTS, Nilai UAS } \\
\text { lalu tekan tombol } \\
\text { Simpan. }\end{array}$ & $\begin{array}{l}\text { Sistem akan menyimpan data } \\
\text { yang sudah dihitung pada form } \\
\text { penilaian mahasiswa ke dalam } \\
\text { database. }\end{array}$ & $\begin{array}{l}\text { Sistem menyimpan } \\
\text { data yang sudah } \\
\text { dihitung ke dalam } \\
\text { database. }\end{array}$ & Berhasil \\
\hline CS5 & $\begin{array}{l}\text { Mengosongkan salah } \\
\text { satu kolom pada form } \\
\text { lalu tekan tombol } \\
\text { Simpan. }\end{array}$ & $\begin{array}{l}\text { Sistem tidak akan } \\
\text { menyimpan data yang sudah } \\
\text { dihitung pada form penilaian } \\
\text { mahasiswa ke } \\
\text { dalam database. }\end{array}$ & $\begin{array}{l}\text { Sistem tidak } \\
\text { menyimpan data } \\
\text { yang sudah } \\
\text { dihitung } \\
\text { ke dalam database. }\end{array}$ & Berhasil \\
\hline CS6 & $\begin{array}{l}\text { Masukan kolom } \\
\text { Nama,NIM, Nilai } \\
\text { Kehadiran, Nilai Tugas, } \\
\text { Nilai UTS, Nilai UAS } \\
\text { lalu tekan tombol Hapus. }\end{array}$ & $\begin{array}{l}\text { Sistem akan menghapus data } \\
\text { yang sudah diisi pada form } \\
\text { penilaian mahasiswa. }\end{array}$ & $\begin{array}{l}\text { Sistem } \\
\text { mengosongkan semua } \\
\text { kolom pada form. }\end{array}$ & Berhasil \\
\hline
\end{tabular}

\section{Kesimpulan}

Berdasarkan pada pengujian yang telah dibahas, dapat diambil kesimpulan bahwa pengujian metode black box terhadap aplikasi hanya berfokus terhadap masukan dan keluaran yang menginformasikan kesesuaian aplikasi yang dikembangkan dengan spesifikasi yang ditetapkan. Hasil pengujian menunjukkan bahwa tingkat keberhasilan aplikasi hanya berjalan sekitar $80 \%$. Sistem tetap mampu menghitung nilai di mana keadaan salah satu kolom dikosongkan. Aplikasi ini perlu diperbaiki lagi untuk meningkatkan kualitas aplikasi dalam menghitung nilai dari $0-100$ sebagaimana fungsinya.

\section{Saran}

Pengujian Aplikasi Penilaian Mahasiswa 
Ini diharapkan dapat menjadi sumber referensi untuk pengujian selanjutnya. Pada penelitian selanjutnya disarankan untuk tidak hanya menggunakan satu metode pengujian, sehingga hasil yang didapatkan bisa lebih valid lagi.

\section{References}

Arwaz, A. A., Putra, K., Putra, R., Kusumawijaya, T., \& Saifudin, A. (2019). Pengujian Black Box pada Aplikasi Sistem Seleksi Pemenang Tender Menggunakan Teknik Equivalence Partitions. Jurnal Teknologi Sistem Informasi dan Aplikasi, 2(4), 130-134. doi:10.32493/jtsi.v2i4.3708

Astuti, P. (2018). Penggunaan Metode Black Box Testing (Boundary Value Analysis) pada Sistem Akademik (SMA/SMK). Faktor Exacta, 11(2), 186-195. doi:10.30998/faktorexacta.v11i2.2510

Aziz, I. A., Setiawan, B., Khanh, R., Nurdiyansyah, G., \& Yulianti, Y. (2020). Pengujian Black Box pada Aplikasi Sistem Kasir Berbasis Website Menggunakan Teknik Equivalence Partitions. Jurnal Teknologi Sistem Informasi dan Aplikasi, $\quad 3(2), \quad$ 10.32493/jtsi.v3i2.4693. doi:10.32493/jtsi.v3i2.4693

Febrian, V., Ramadhan, M. R., Faisal, M., \& Saifudin, A. (2020). Pengujian pada Aplikasi Penggajian Pegawai dengan menggunakan Metode Blackbox. Jurnal Informatika Universitas Pamulang, 5(1), 61-66. doi:10.32493/informatika.v5i1.4340

Hendri, H., Manurung, J. W., Ferian, R. A., Hanaatmoko, W. F., \& Yulianti, Y. (2020). Pengujian Black Box pada Aplikasi Sistem Informasi Pengelolaan Masjid Menggunakan Teknik Equivalence Partitions. Jurnal Teknologi Sistem Informasi dan Aplikasi, 3(2), 107-113. doi:10.32493/jtsi.v3i2.4694

Jaya, T. S. (2018). Pengujian Aplikasi dengan Metode BlackBox Testing Boundary Value Analysis (Studi Kasus: Kantor Digital Politeknik Negeri Lampung). Jurnal Informatika: Jurnal Pengembangan IT (JPIT), Vol.03, No.02, 45-48.

Krismadi, A., Lestari, A. F., Pitriyah, A., Mardangga, I. W., Astuti, M., \& Saifudin, A. (2019). Pengujian Black Box berbasis Equivalence Partitions pada Aplikasi Seleksi Promosi Kenaikan Jabatan. Jurnal Teknologi Sistem Informasi dan Aplikasi, 2(4), 155-161.

Kurniawan, T. A. (2017). Pengujian Perangkat Lunak. Pengujian Struktur Program Dengan Pengujian Jalur Dasar (Basic Path Testing) : Teori dan Aplikasi, 24-32.

Liana, L. (2015). Pengujian Perangkat Lunak. Pengujian Perangkat Lunak, 1-15.

MZ, M. K. (2016). Pengujian Perangkat Lunak Metode Black-Box Berbasis Equivalence Partitions Pada
Aplikasi Sistem Informasi Sekolah. Mikrotik, 27.

Ningrum, F. C., Suherman, D., Aryanti, S., Prasetya, H. A., \& Saifudin, A. (2019). Pengujian Black Box pada Aplikasi Sistem Seleksi Sales Terbaik Menggunakan Teknik Equivalence Partitions. Jurnal Informatika Universitas Pamulang, 4(4), 125-130.

Saifudin, A., \& Yulianti, Y. (2020). Dimensional Reduction on Cross Project Defect Prediction. Journal of Physics: Conference Series. 1477, p. 022030. Tangerang: IOP Publishing. doi:10.1088/1742-6596/1477/3/032011

Wahyu, Y. S. (2018). Pengujian Black Box Testing Pada Aplikasi Action \& Strategi Berbasis Andriod Dengan Teknologi Phonegap. Jurnal String Vol. 3 No.2, 206-208. 